DOI: 10.20472/TEC.2019.008.014

\title{
DONNAVAN KRUGER
}

North-West University, South Africa

JOSEF DE BEER

North-West University, South Africa

\section{INFUSING INDIGENOUS KNOWLEDGE IN THE LIFE SCIENCES CLASSROOM: DESIGN PRINCIPLES FOR CREATING AN ETHNOBIOLOGICAL MATRIX}

\begin{abstract}
:
A perennial problem facing South African science education is how to better contextualize curriculum content to a diverse student population. South Africa, who is often dubbed the 'rainbow nation' because of its racial and cultural diversity, also has to deal with a large spectrum of students in terms of socio-economic status. In especially rural parts of the country, where indigenous knowledge is thriving, the 'western' science curriculum is not always accessible to all learners. By infusing relevant indigenous knowledge into curriculum themes, students will be able to better understand and appreciate the value of science in everyday life. Despite fundamental differences between the natural sciences and Indigenous Knowledge (IK) (e.g. the holistic nature of IK versus the reductionist nature of science), similarities in the processes also exist, e.g. the empirical, tentative and inferential nature of both. The responsibility thus lies with teacher educators to train teachers on how to effectively infuse IK in the classroom. This paper describes a rigorous method to create science context by means of ethnobiological studies which will be implementable in teacher education and ultimately infused in science classrooms. The research draws on the Matrix Method that was developed by De Beer and Van Wyk in the field of ethnobotany, and in this paper, the authors show how ethnozoology could also be included. The Matrix Method affords students the opportunity to, as scientific sleuths, engage in project-based learning, while also developing more nuanced understandings of the role that science plays in everyday life. Although the context is South African, the heuristic developed has universal application and could be used in any country.
\end{abstract}

\section{*ACKNOWLEDGEMENTS:}

This work is based on a research project supported by the National Research Foundation (NRF) of South Africa (Grant Number 114333). The grant holder acknowledges that opinions, findings and conclusions or recommendations expressed in any publication generated by the NRF-supported research are those of the author(s), and that the NRF accepts no liability whatsoever in this regard.

\section{Keywords:}

contextualized teaching and learning, curriculum policy, design principles, ethnobotany, ethnobiology, ethnozoology, indigenous knowledge, Matrix, problem-based learning, project-based learning

JEL Classification: 124, 125, 129 


\section{Introduction and problem statement}

The use of plant and animal products for medicine was perceived as witchcraft and wizardry in Apartheid South Africa. Traditional healers were referred to as "witch doctors" for using plants and animal parts, or combinations thereof, as well as for their engagement in spirituality, to heal ailments and illnesses (Schons, 2011). The institution of the Suppression of Witchcraft Act 3 (1957) marginalized the people that practised this traditional healing due to the metaphysical aspect that accompanies it. However, the knowledge of each medicament was a result of centuries of knowledge transfer within traditional cultures in southern Africa that forms part of what we now refer to as indigenous knowledge (IK). Therefore, it is reasonable that the inclusion of teaching IK was made one of the central teaching principles in the South African curriculum policy in the new democracy (post 1994).

The curriculum policy provides specific guidelines to teachers to value indigenous knowledge systems (IKS) by "acknowledging the rich history and heritage of this country as important contributors to nurturing the values contained in the Constitution" (DBE, 2011:5). Further, instruction is built into the specific aims to teach "the history of scientific discoveries and the relationship between indigenous knowledge and science" (DBE, 2011:13). However, South African teachers are not trained in infusing IK in the classroom (Mothwa, 2011; De Beer, 2016). When science teachers do infuse IK, they merely pay "lip service" to the topic by mentioning a few examples, e.g. the utilization of the Cancer Bush (Sutherlandia frutescens) for treating fevers (De Beer, 2016). However, there is no reference to the processes of science and no glance on the tenets of scientific thought in the development of IK.

Indigenous knowledge is not detached from scientific thought. Even though there are fundamental differences among the natural sciences and IK (e.g. reductionism versus holism respectively), similarities in the processes of natural science and indigenous knowledge also exist, e.g. the empirical, tentative and inferential nature of both (Cronje, 2015). The responsibility thus lies with teacher educators to train teachers on how to effectively infuse IK in the classroom. This paper will describe rigorous methods to create science context by means of ethnobiological studies which will be implementable in teacher education and ultimately infused in classrooms. The authors argue that the Matrix Method described in the paper could enhance self-directed learning skills necessary in a complex $21^{\text {st }}$ century.

\section{$2 \quad$ Literature review}

\section{Bringing it home: the value of contextualized teaching and learning}

Constructivism is a teaching and learning approach that theorizes how new knowledge is embedded within pre-existing knowledge and is, therefore, affected by the context in which knowledge is presented (Bada and Olusegun, 2015:66). By following a constructivist approach in the classroom, lessons should pivot around the process of knowledge construction (not transmission), guided by clearly defined learning objectives within context-based activities. Relevance in the classroom immediately connects students' prior knowledge and answers the "Why do we need to know this?" question which leads to a more engaged learning process 
(Shan, 2011). As a theoretical framework, we build on social constructivism (Vygotsky, 1978), and how an ethnobiological heuristic could be used to scaffold learning across Vygotsky's 'zone of proximal development'.

\section{Teaching and learning contextualized science}

It has been long known that perceptions of instruction are positively correlated to attitudes towards science, which in turn positively influence achievement (Schibeci and Riley, 1986). Students' perceptions of the relevance of science can also be tied to the development index of a country (Sjøberg and Schreiner, 2006). The relevance of science in our daily lives is critical to shaping the attitudes of students towards science. A recent study by Schmidt et al. (2019) showed how relevance statements in the science classroom were positively correlated to students' perception of the usefulness of science in their lives. This leads us to the question: How do we make science education more relevant to students?

Infusing IK into the science classroom brings relevance to students who are of the applicable ethnic origin of the specific IK examples that are used, creates a sense of pride, and connects all learners to the cultural history of science. Additionally, taking cognizance of IK's role in science has ethical and cultural lesson objectives in the "hidden" curriculum. By infusing IK into the sciences classroom, ample opportunities are provided to address one of the goals in the African National Congress's (ANC's) National Health Plan (1994), as referenced by De Beer and Van Wyk (2011a), which declares that "people have the right of access to traditional practitioners as part of their cultural heritage and belief system." We build our argument for the epistemological border-crossing between natural sciences and indigenous knowledge on insights from the learning psychology field, notably embodied, situated and distributed cognition (ESDC) (HardyVallee and Payette, 2008). Such an ESDC perspective sees cognition as being "physiologically embodied, socioculturally situated, and ostensibly distributed among individuals" (Chahine, 2013:434).

\section{Drawing upon ethnobiological knowledge}

The scientific field of study, ethnoecology, combines the words ethno, denoting to humans and human behavior, and ecology, the study of the interactions between organisms and the physical environment. Ethnoecology is the study of how people from different cultures in different locations interact with the ecosystems they are living in, which is encapsulated in indigenous ecological knowledge (Posey et al., 1984; Nazarea, 1999). For this paper, we refer specifically to studies that are concerned with indigenous peoples' interactions with the natural environment (Martin, 1995).

Indigenous peoples of arid southern Africa had to rely on what the region offered in order to survive this hostile environment with scamp resources for food and drink. They had to make meticulous observations of their environment to draw connections between cause and effect, embodied in the physical, social, cultural, and metaphysical knowledge systems of the time. This holistic approach to observing the natural environment (as opposed to the reductionist approach of science), has led to assumptions that the contemporary scientist will grapple to understand and 
might see them as 'unnatural'. However, after careful thought and root-cause-analysis is applied to these assumptions, the science that grounds the observations can be extracted. Two subdisciplines of ethnoecology that is of particular interest in the life sciences are ethnobotany and ethnozoology.

There has been a considerable amount of literature published on the topic of ethnobotany, the study of the relationships between plants and people (see Van Wyk and Gericke (2000) for a southern Africa account). This is probably partly due to the inherent medicinal properties of plants and their importance in the pharmacological industry. Consequently, methods to incorporate ethnobotany as part of the indigenous knowledge infusion in the life sciences classroom, has received some attention (De Beer and Van Wyk, 2011a, 2011b). However, ethnozoology has been unduly neglected in South Africa.

Ethnozoology (also referred to as anthrozoology) is the study of the interrelationships between animals and people and have a number of subdisciplines according to the major taxonomic groups of animals, which includes ethnoherpetology (reptiles and amphibians), ethnoichthyology (fish), ethnoentomology (insects), ethnoornithology (birds), ethnoprimatology (primates), ethnomammalogy (all mammals), and ethnotaxonomy (the study of naming organisms). The few ethnozoological studies concerning South African cultures that are available mainly focus on the conservation issues of the animals used in trade (Whiting et al., 2013). People selling animals and animal parts at the famous Faraday Market in South Africa are usually secretive about the uses of animals, probably due to the questionable legality of their uses and origins and the retention intellectual property (Whiting et al., 2013).

\section{Methodology}

This conceptual paper focuses on the need for and the affordances of ethnobiological surveys in school science education. However, the design principles that were used in the development of these instruments and methodology, were distilled from data collected from design-based research (DBR) conducted over a five-year period (2015 - 2019). The DBR focused on science teachers engaging in short learning programmes on indigenous knowledge (as part of their professional development). The basic methodology used in this paper is based on the Matrix Method (De Beer and Van Wyk, 2011a, 2011b). The Matrix Method was conceptualized as a quantitative method to record ethnobotanical knowledge of people in a particular community. The method also introduced two new terms- the Ethnobotanical Knowledge Index (EKI) (a quantitative measure of a person's knowledge of local plant use), and the Species Popularity Index (SPI), a quantitative measure of the importance or popularity of a plant species (De Beer and Van Wyk, 2011:742). In order to provide an instrument that provides insight into local knowledge of not just plants, but also animals, the first prototype of an ethnobiological instrument was developed and piloted, making provision for both ethnobotanical as well as ethnozoological knowledge. This resulted in coining a new term, the Ethnobiological Knowledge Index (EBKI), as it distinguishes itself from the Ethnobotanical Knowledge Index (EKI) by also including knowledge on ethnozoology. 


\section{$4 \quad$ The Matrix Method for ethnobiological surveys}

De Beer and Van Wyk (2011b:743) conceptualized the Matrix Method as "a quantitative method to rapidly quantify ethnobotanical knowledge". These authors describe how participants are shown herbarium voucher specimens of plants, and are then requested to answer the following questions: (1) Do you know the plant?, (2) Can you provide any names for the plant?, and (3) Can you recall any uses of the plant (e.g. as food source, for medicines, or arts and crafts)? These responses are then recorded by the researcher, and entered into a Matrix. To each of the three questions, a numerical value is allocated. If a person knows the plant, 1 mark is allocated. Providing name(s) for the plant secures another 2 marks, and for providing uses for the plant, a potential 3 marks can be obtained. For each person, a numerical value out of a possible 6 is provided, for each plant, as can be seen in Figure 1. The fourth digit (in bold) is the sum total of the other three numbers. For example, person JB, knew Acacia karroo and could recognize it (and scored 1 mark), could provide vernacular (common) names for the plant (and scored another 2 marks), and could also provide uses of the plant in terms of food or medicine (an additional 3 marks), therefore scored 6 (in bold) for this particular plant.

Figure 1: An excerpt from the Matrix of De Beer and Van Wyk (2011b:751), illustrating the Species Popularity Index (SPI) and the Ethnobotanical Knowledge Index (EKI).

\begin{tabular}{|l|c|c|c|c|c|c|}
\hline Species & JB & DB & HB & HG & IW & SPI \\
\hline Acacia karroo & 1236 & 1236 & 1001 & 1236 & 1236 & 0.54 \\
\hline Agathosma betulina & 1236 & 0000 & 0000 & 1001 & 0000 & 0.08 \\
\hline Aloe dichotoma & 1236 & 1203 & 1203 & 1203 & 1203 & 0.66 \\
\hline Aloe ferox & 1236 & 1034 & 1001 & 1236 & 1203 & 0.60 \\
\hline Aloe microstigma & 1236 & 1236 & 1203 & 1236 & 1236 & 0.97 \\
\hline Aloe variegata & 1236 & 1236 & 1203 & 1236 & 0000 & 0.38 \\
\hline EKI & 0.93 & 0.68 & 0.56 & 0.61 & 0.20 & \\
\hline
\end{tabular}

De Beer and Van Wyk (2011b:743) explain how each participant's ethnobotanical knowledge index (EKI) was determined, as being a fraction of the maximum score possible. In their survey they have used 64 plants, and the maximum score possible is therefore $64 \times 6=384$. In the case of $\mathrm{JB}$, a score of 356 was obtained for the 64 plants showed to him, and 356 divided by 384 gives $\mathrm{JB}$ an EKI of 0.93, which is excellent. (Figure 1 only shows an excerpt of De Beer and Van Wyk's Matrix). In their survey, 16 participants participated (only five are shown in Figure 1), and based on their collective knowledge of each plant species, the Species Popularity Index (SPI) was determined for every plant. For sixteen participants, each obtaining a maximum score of 6 per plant species, a maximum possible score of 96 is possible. Agathosma betulina scored 8 among the 16 participants, and 8 divided by 96 gives an SPI of 0.08 . The SPI provides insight into the popularity or importance of the plant in a specific community.

De Beer and Van Wyk (2011a) makes the statement that, when dealing with indigenous knowledge in the life sciences classroom, the danger always exists that one may unintentionally promote pseudo-science. The Matrix Method therefore holds affordances for introducing indigenous knowledge in a scientifically rigorous way in the life sciences classroom. Students are 
expected to engage in a scientific survey, and in the process they not only learn about fauna and flora, but also develop mathematical skills.

However, this pioneering work of De Beer and Van Wyk (2011a, 2011b) did not address ethnozoology. We have therefore piloted a simple heuristic, to make teachers, attending a short learning programme, aware of such a methodology. In Figure 2 we provide a simple questionnaire, in which teachers had to indicate whether they know the organism, have names for it, as well as possible uses, and they were then shown how to populate this data into a Matrix (Figure 3). 
Figure 2: The ten animal and plant species used in the pilot project. (In the last row, we provide a brief synopsis of the species).

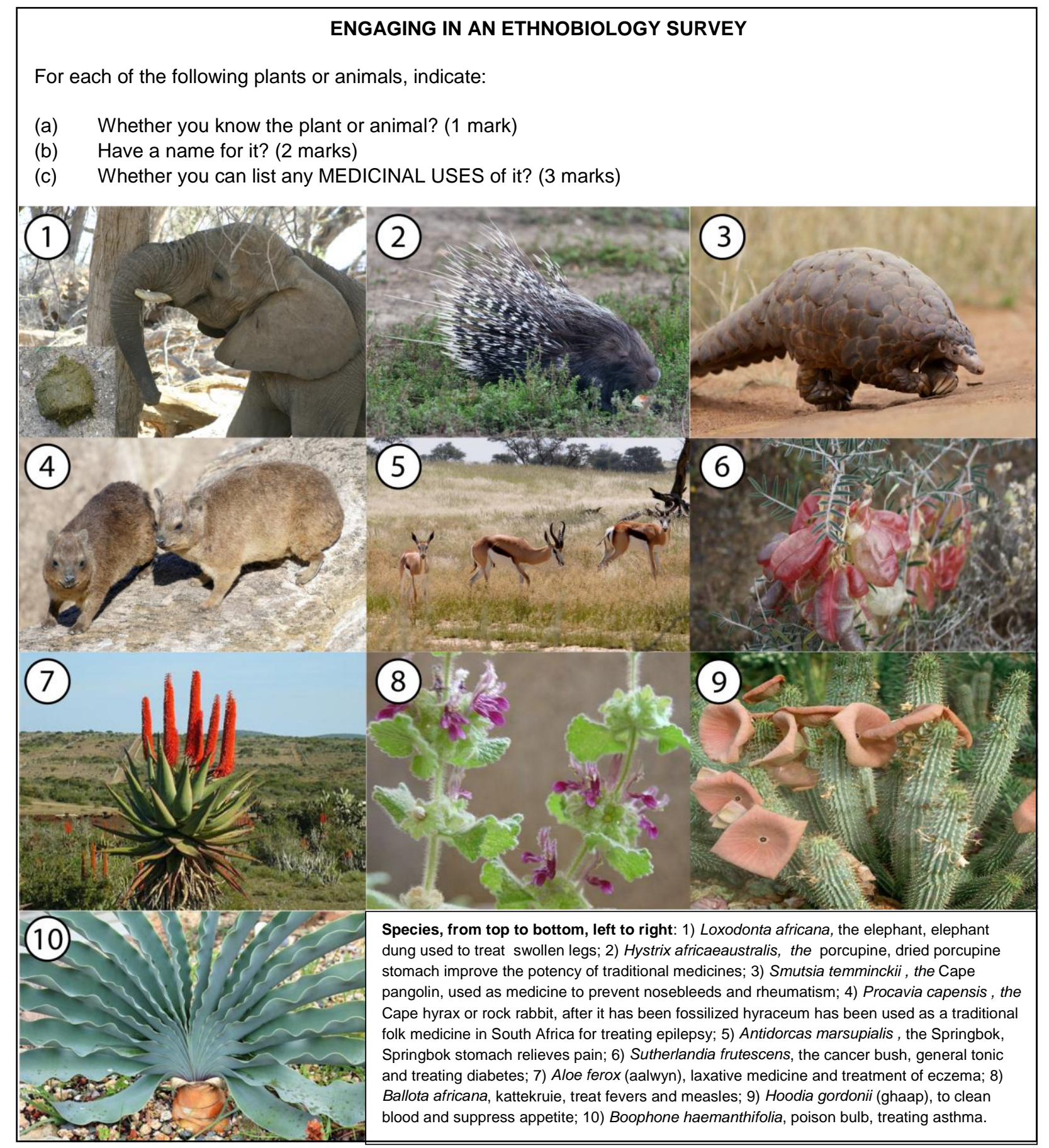


Figure 3: The ethnobiology matrix, used by participants to determine the SPI and EBKI (Ethnobiological knowledge index, a rhizomic development on De Beer and Van Wyk's Ethnobotanical knowledge index) values.

ETHNOBIOLOGY MATRIX

\begin{tabular}{|l|l|l|l|l|l|l|l|l|l|l|l|}
\hline & $\mathrm{A}$ & $\mathrm{B}$ & $\mathrm{C}$ & $\mathrm{D}$ & $\mathrm{E}$ & $\mathrm{F}$ & $\mathrm{G}$ & $\mathrm{H}$ & $\mathrm{I}$ & $\mathrm{J}$ & SPI \\
\hline $\begin{array}{l}\text { Loxodonta } \\
\text { africana }\end{array}$ & ---- & ---- & ---- & ---- & ---- & ---- & ---- & ---- & ---- & ---- & \\
\hline $\begin{array}{l}\text { Hystrix } \\
\text { africaeaustralis }\end{array}$ & ---- & ---- & ---- & ---- & ---- & ---- & ---- & ---- & ---- & ---- & \\
\hline $\begin{array}{l}\text { Smutsia } \\
\text { temminckii }\end{array}$ & ---- & ---- & ---- & ---- & ---- & ---- & ---- & ---- & ---- & ---- & \\
\hline $\begin{array}{l}\text { Procavia } \\
\text { capensis }\end{array}$ & ---- & ---- & ---- & ---- & ---- & ---- & ---- & ---- & ---- & ---- & \\
\hline $\begin{array}{l}\text { Antidorcas } \\
\text { marsupialis }\end{array}$ & ---- & ---- & ---- & ---- & ---- & ---- & ---- & ---- & ---- & ---- & \\
\hline $\begin{array}{l}\text { Sutherlandia } \\
\text { frutescens }\end{array}$ & ---- & ---- & ---- & ---- & ---- & ---- & ---- & ---- & ---- & ---- & \\
\hline $\begin{array}{l}\text { Aloe } \\
\text { ferox }\end{array}$ & ---- & ---- & ---- & ---- & ---- & ---- & ---- & ---- & ---- & ---- & \\
\hline $\begin{array}{l}\text { Ballota } \\
\text { africana }\end{array}$ & ---- & ---- & ---- & ---- & ---- & ---- & ---- & ---- & ---- & ---- & \\
\hline $\begin{array}{l}\text { Hoodia } \\
\text { gordonii }\end{array}$ & ---- & ---- & ---- & ---- & ---- & ---- & ---- & ---- & ---- & ---- & \\
\hline $\begin{array}{l}\text { Boophone } \\
\text { disticha }\end{array}$ & ---- & ---- & ---- & ---- & ---- & ---- & ---- & ---- & ---- & ---- & \\
\hline EBKI & & & & & & & & & & & \\
\hline
\end{tabular}

\section{Design principles that underpinned the development of the Ethnobiology Matrix Method}

The instrument was based on the Matrix Method of De Beer and Van Wyk (2011b). However, the pedagogy of how to implement such ethnobiological surveys in the science classroom was informed from design principles that were distilled from the data collected during various cycles of presenting short learning programmes to the teachers. These design principles are explained in the section that follows.

a) The Ethnobiology Matrix Method is underpinned by problem-based and project-based approaches

Students should engage in the Ethnobiology Matrix Method as project-based learning. Krajcik and Shin (2016:276) list six key characteristics of project-based learning:

- $\quad$ Project-based learning (PBL) is driven by a driving question. In this case, the driving question is, "what knowledge do people have about the medicinal value of selected plants and animals?"

- The focus of PBL is on learning goals that students should achieve. In this case, students should acquire the skills to engage in ethnobiological surveys and to accurately record and analyze the data. 
- While exploring the driving question, the students should participate in scientific practices. They should engage in research activities such as conducting interviews with people, record and analyze data and report the findings.

- Students should engage in collaborative activities. Cooperative learning should be enhanced, e.g. students could work in small groups on the project.

- In the learning (research) project, the students are scaffolded - e.g. support should be provided to the students in order to ensure that the outcomes are achieved.

- $\quad$ The students should develop a project (artefact), e.g. they should report their findings in the form of an academic paper, a poster, or a science expo project.

\section{b) Context should be kept in mind.}

Whereas we developed a pilot instrument with common plant and animal species, customized instruments should be developed for different regions, drawing on the unique plant- and animal species occurring in that region.

\section{c) It is of crucial importance that the science teacher provides the learners with a good understanding of the nature (tenets) of respectively science and indigenous knowledge.}

Cronje (2015:37-41) has shown that both western science and indigenous knowledge share several tenets, e.g. both are empirical (nature and its processes are observable and testable), tentative (subject to change), inferential (deductions or conclusions are made, based on observations), creative (human creativity is an important factor), subjective (although scientists strive to be objective, human beings are subjective and are influenced by prior knowledge, beliefs and biases), and socially and culturally influenced (science is a human endeavor, and affected by social and cultural milieu). However, there are also important differences. Whereas science is absolutely empirical, indigenous knowledge has, in addition to its partly empirical nature, also a metaphysical component. Furthermore, whereas western science is reductionist, indigenous knowledge is holistic. The latter two differences will provide students with more nuanced understandings of the two epistemologies. When doing the ethnobiological surveys, they will quickly distinguish between aspects of indigenous knowledge that are in line with scientific principles (e.g. medicinal plant use based on years of observation and experimentation), and metaphysical beliefs (e.g. 'magical' use of biotic material). However, De Beer and Van Wyk (2019) show that there are often plausible explanations for, what at first sight, might be seen as 'magic' or 'pseudoscience'. For instance, traditionally the stems of the plant creeper 'impinda' (Adenia gummifera) was used to keep 'evil spirits' away. A decoction of the plant material was traditionally sprinkled around the house. Through careful observation indigenous knowledge holders have realized that impinda has strong antimicrobial properties, and therefore indeed effective in preventing disease caused by pathogens. Although its use sound irrational at first, it is clear that there is a rational explanation for its use. The ethnobiological survey will provide 
students with more nuanced understandings of both the tenets of science and indigenous knowledge.

\section{d) Self-directed learning should be enhanced during the project.}

Knowles (1975:18) describes self-directed learning as the "process in which individuals take the initiative, with or without the help of others, in diagnosing their learning needs, formulating learning goals, identifying human and material resources, choosing and implementing appropriate learning strategies and evaluating learning outcomes". While engaging in the ethnobiology project, students will experience various problems, and based on this, they will set learning goals for themselves. For example, the student might realize that he/she needs to learn more about interview skills. The student will therefore set this as a learning goal, and will have to decide upon a strategy, and identify the necessary learning resources, to achieve the learning goal.

\section{Conclusion}

Implementing ethnobiological surveys in the life sciences classroom can connect students with the cultural and traditional roots of science. The design principles described that underpin the development of the Ethnobiology Matrix Method will be a useful guide when creating a contextualized learning experience when infusing indigenous knowledge in the life sciences classroom. When school students use this Matrix Method, they engage in authentic science as scientific sleuths, and in the process they develop more nuanced understandings of the tenets of science. It could also assist students in developing more nuanced understandings of the role of science in everyday life. Problem-based learning holds affordances for enhancing self-directed learning in learners, and in doing so, prepare them for a complex $21^{\text {st }}$ century. Although South African examples have been used in this research paper, the Matrix Method can easily be used in any cultural context. Educators using the Matrix Method, could identify suitable plant or animal species based on either the Species Popularity Index (De Beer and Van Wyk, 2011), or the Salience Index ((Pirker, Haselmair, Kuhn, Schunko and Vogl, 2012). The latter index indicate which are the most prominent species in terms of human use in a particular place. For instance, in Tyrol, Austria, Urtica dioica and Arnica montana are respectively important plants used for medicinal purposes, and these species would be good choices in ethnobiological surveys.

\section{References}

BADA, S. O. and OLUSEGUN, S. (2015). Constructivism learning theory: A paradigm for teaching and learning. Journal of Research and Method in Education, 5(6), 66 - 70.

CHAHINE, I. C. (2013). The impact of using multiple modalities on students' acquisition of fractional knowledge: An international study in embodies mathematics across semiotic cultures. Journal of Mathematical Behavior 32, $434-449$. 
CRONJE, A. (2015). Epistemological border-crossing between western science and indigenous knowledge and its implications for teacher professional development. University of Johannesburg, Unpublished PhD thesis.

DBE. (2011). Curriculum and Assessment Policy Statement (CAPS): Further Education and Training Phase Life Sciences, Grades 10-12. Department for Basic Education, Pretoria.

DE BEER, J. (2016). Re-imagining science education in South Africa: The affordances of indigenous knowledge for self-directed learning in the school curriculum. Journal for New Generation Sciences 14(3), 34 - 53.

DE BEER, J. J. J. and VAN WYK, B-E. (2011a). Doing an ethnobotanical survey in the Life Sciences classroom. The American Biology Teacher 73(2), 90 - 97.

DE BEER, J. J. J. and VAN WYK, B-E. (2011b). An ethnobotanical survey of the Agter-Hantam, Northern Cape Province, South Africa. South African Journal of Botany (2011) 77, 741 754.

DE BEER, J. J. J., and VAN WYK, B-E. (2019). Arguing for the inclusion of indigenous knowledge in the STEM curriculum: Possibilities and challenges. In: J.J.J. de Beer, The decolonization of the curriculum project: The affordances of indigenous knowledge for self-directed learning. AOSIS, Cape Town.

HARDEE-VALLEE, B., and PAYETTE, N. (2008). Beyond the brain: Embodied, situated and distributed cognition. Cambridge Scholars Publishing, Newcastle.

KNOWLES, M. S. (1975). Self-directed learning: A guide for learners and teachers. Prentice Hall, Englewood Cliffs.

KRAJCIK, J. S., and SHIN, N. (2016). Project-based learning. In: Sawyer, R.K. (Ed), The Cambridge Handbook of the Learning Sciences, Cambridge University Press, DOI: http://dx.doi.org/10.1017/CB09781139519526

MARTIN, G. J. (1995). Ethnobotany - A 'People and Plants' Conservation Manual. London, UK: Chapman \& Hall.

MOTHWA, M. M. (2011). Teachers' experiences of incorporating indigenous knowledge in the Life Sciences classroom. Unpublished Master's dissertation, University of Johannesburg.

NAZAREA, V. D. ed. (1999). Ethnoecology: situated knowledge/located lives. University of Arizona Press.

PIRKER, H., HASELMAIR, R., KUHN, E., SCHUNKO, C., and VOGL, C. (2012). Transformation of traditional knowledge of medicinal plants: the case of Tyroleans (Austria) who migrated to Australia, Brazil and Peru. Journal of Ethnobiology and Ethnomedicine, 8(44), 1- 26.

POSEY, D. A., FRECHIONE, J., EDDINS, J., DA SILVA, L. F., MYERS, D., CASE, D. and MACBEATH, P. (1984). Ethnoecology as applied anthropology in Amazonian development. Human organization, 43(2), pp.95-107.

SCHIBECI, R. A. and RILEY, J. P. (1986). Influence of students' background and perceptions on science attitudes and achievement. Journal of Research in Science teaching, 23(3), 177 187. 
SCHMIDT, J. A., KAFKAS, S. S., MAIER, K. S., SHUMOW, L. and KACKAR-CAM, H. Z. (2019). Why are we learning this? Using mixed methods to understand teachers' relevance statements and how they shape middle school students' perceptions of science utility. Contemporary Educational Psychology, 57, 9-31.

SCHONS, M. (2011). Witch Trials in the 21st Century. National Geographic Education. Web: http://media.nationalgeographic.org/assets/reference/assets/witch-trials-21 st-century-1.pdf

SHAN, Y. W. 2011. Contextualised teaching towards active learning. Centre for Development of Teaching and Learning Brief, 14(2), 1 - 3.

SJØBERG, S. and SCHREINER, C. (2006). How do learners in different cultures relate to science and technology? APFSLT: Asia-Pacific Forum on Science Learning and Teaching, 7(1).

Suppression of Witchcraft Act 3. (1957). Pretoria, South Africa: Government Printers.

VAN WYK, B. E. and GERICKE, N. (2000). People's plants: A guide to useful plants of Southern Africa. Briza Publications.

VYGOTSKY, L. S. (1978). Mind in society. London: Harvard University Press.

WHITING, M. J., WILLIAMS, V. L. and HIBBITTS, T. J. (2013). Animals traded for traditional medicine at the Faraday market in South Africa: species diversity and conservation implications. In Animals in traditional folk medicine (pp. 421-473). Springer, Berlin, Heidelberg. 